\title{
A ORIGEM CRISTÃ DO EXISTENCIALISMO DO SÉCULO XX: UMA INVESTIGAÇÃO A PARTIR DE LUIGI PAREYSON
}

The Christian origin of 20th century existentialism: an investigation based on Luigi Pareyson

Marcio Gimenes de Paula *

Resumo: A partir das reflexões do filósofo italiano Luigi Pareyson expostas nas obras Studi sull'esistenzialismo e Ontologia della libertà, o artigo almeja aprofundar a discussão sobre dois pontos: a origem cristã da reflexão sobre a existência no século $X X$ e o tema da liberdade em tal ontologia proposta pelo pensador. Os dois temas são capitais na história do existencialismo do século XX. A primeira tese nos parece instigante por polemizar com a tese ateísta ou agnóstica e a segunda por desenvolver um tema central da reflexão filosófica tanto no seu aspecto ontológico como moral.

Palavras-chave: Ética. Existencialismo. Filosofia da Religião. Luigi Pareyson. Ontologia.

Abstract: Based on the reflections of the Italian philosopher Luigi Pareyson in his works Studi sull'esistenzialismo and Ontologia della libertà, the article aims to further the discussion on two themes: the Christian origin of the reflection on existence in the 20th century and the topic of freedom in the ontology proposed by the author. Both themes are central to the history of 20th century existentialism. We find the first thesis riveting for its controversy with the atheistic or

\footnotetext{
* Professor do Departamento de Filosofia da Universidade de Brasília (UnB). Artigo recebido em 16/09/2020 e aprovado para publicação em 20/10/2020.
} 
agnostic thesis and the second for developing a central theme of philosophical reflection in its ontological and moral aspects.

Keywords: Ethics. Existentialism. Philosophy of Religion. Luigi Pareyson. Ontology.

\section{Considerações introdutórias}

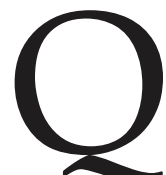

uando pensamos nas origens cristãs do existencialismo parece que, quase inevitavelmente, também nos deparamos com a pergunta pelo futuro da religião. Em nosso contexto a pergunta se volta mais especificamente ao futuro da religião cristã. Talvez, notadamente no século XX, a pergunta pelo sentido e, portanto, pelo futuro da religião foi também formulada por boa parte do existencialismo seguindo a esteira das críticas do século XIX. Entretanto, sob o nome de existencialismo se abrigam muitas concepções diversificadas e, inclusive, opostas. Por isso, urge fazer uma melhor separação delas a fim de alcançar uma compreensão mais efetiva.

É verdade, entretanto, que o existencialismo - nas suas diversas matizes - é também herdeiro direto da dissolução do hegelianismo do século XIX. Contudo, é igualmente verdade que, no meio dos tantos "existencialismos", nem todos deram a mesma resposta para as perguntas formuladas.

Assim, o existencialismo do filósofo italiano Luigi Pareyson, que será o objeto do nosso trabalho, parece se constituir exatamente como uma significativa resposta do existencialismo cristão aos desafios do seu tempo. Herdeiro da filosofia de Pascal, do paradoxo kierkegaardiano, do problema da liberdade em Schelling e dos desafios do cristianismo expostos na aguda literatura filosófica de Dostoievski, o filósofo abarca, nos seus textos, aspectos muitos instigantes da filosofia contemporânea do século XX e das humanidades.

Aqui devemos evitar um pensamento apressado que, talvez, tenderia a enfatizar que se Pareyson é um filósofo "religioso" logo as questões já estão respondidas de saída. Tal coisa seria simplória demais e não faria justiça aos desafios por ele postos. O primeiro ponto a se problematizar é que Pareyson, na mesma senda de Kierkegaard e Heidegger, toma todo "pensador religioso" em altíssima conta, o que já muda totalmente a interpretação convencionalmente dada. Assim temas que na sua filosofia aparecem tão bem desenvolvidos como a discussão sobre os mitos, a hermenêutica, o paradoxo, a escatologia, o livre-arbítrio, a incompreensibilidade de Deus são igualmente temas do universo do religioso e da teologia. O que muda 
é que o filósofo, evitando todo idealismo ou racionalismo, dará novo significado a eles, o que nos parece profundamente instigante e promissor.

O filósofo foi formado numa tradição europeia existencialista e, notadamente por influência do contexto italiano, conhecia bem os debates entre o idealismo e o atualismo, tão em voga no seu tempo. Conviveu igualmente com os pensadores da fenomenologia e do espiritualismo filosófico, movimentando-se em tal terreno, bem como no vasto mundo da estética e da literatura, tal como a de Dostoeivski, por exemplo. Assim, veremos, num primeiro momento, numa de suas primeiras exposições, uma compreensão panorâmica do existencialismo e a afirmação da origem cristã das teses existencialistas. No segundo momento, adentraremos na discussão acerca da liberdade humana num dos seus últimos trabalhos e aqui o foco será a exposição da sua ontologia da liberdade e de um mito caro aos existencialistas do século XX.

\section{A origem cristã da reflexão sobre a existência em Luigi Pareyson: uma análise a partir do Studi sull esistenzialismo}

Luigi Pareyson possui uma leitura singular do existencialismo e, talvez, a despeito de ter sido inicialmente defendida nos anos 30 e 40 do século passado, mereça ser revisitada. No seu entender, o existencialismo é algo complexo, profundo, e não poderia - ou deveria - ser reduzido a uma espécie de mero modismo filosófico como, talvez, tenha sido entendido notadamente na segunda metade do século XX em alguns contextos. Por isso, o juízo do pensador chega até mesmo a ser muito severo com Sartre neste quesito: “ ... é necessário todavia notar que Sartre conseguiu aquela atenção, ainda que não benévola, que outros existencialistas não conseguiram despertar, talvez em virtude da sua atividade de escritor. ${ }^{1}$

Hannah Arendt não toma tal coisa de modo tão radical e nem é tão enfática com a dita "vulgarização" ou "popularização", mas vê nisso até mesmo um mérito acerca do qual a filosofia poderia se beneficiar:

Uma palestra sobre filosofia provoca um tumulto, centenas se aglomerando para entrar e milhares indo embora. Livros com problemas filosóficos que não pregam doutrinas baratas e não oferecem nenhuma panaceia - pelo contrário, tão difíceis que requerem uma verdadeira reflexão - vendem como romances policiais. ${ }^{2}$

${ }^{1}$ PAREYSON, L. Studi sull'esistenzialismo, Mursia, 2001, p. 35.

2 ARENDT, H. Compreender - formação, exílio e totalitarismo, Companhia das Letras, São Paulo, 2008, p. 217. 
A partir do mesmo Sartre, Pareyson igualmente mostra-se crítico de uma abordagem do existencialismo que, aos seus olhos, não parece fazer justiça ao melhor desta tradição:

... hoje o teatro de Sartre e dos seus colegas em arte surge sob o ambíguo nome de teatro "existencialista", e de existencialismo se fala a propósito de romancistas, de poetas, de críticos, tanto que é mesmo avançada a suspeita que o existencialismo seja uma filosofia que por força da sua própria natureza se desenvolve em não-filosofia. ${ }^{3}$

Isso não quer dizer, contudo, que Pareyson tomava Sartre como um filósofo deficitário ou que tenha qualquer problema pessoal em construir um diálogo filosófico com a análise literária ${ }^{4}$ e outras formas artísticas, mas talvez, aponte sua crítica para um determinado tipo de seguidores do pensador e determinadas escolas. A fim de evitar tal coisa, Pareyson nos seus Studi sull'esistenzialismo que é, na verdade, uma coletânea de ensaios escritos em épocas diversas e posteriormente publicados em conjunto, aponta para as fontes do existencialismo. No seu entender, elas seriam, principalmente, três: um existencialismo germânico, um existencialismo francês e um existencialismo russo. Vejamos o que ele mesmo aponta nessa espécie de panorama:

Com estes expedientes será possível distinguir no existencialismo três correntes: uma alemã, uma francesa e uma russa; não se creia aqui tratar-se de uma distinção puramente exterior, pois quando se tem em mente que a corrente alemã se refere a Kierkegaard, que aquela russa apela conscientemente a Dostoievski, e que por trás da corrente francesa está vivo e operante o pensamento de Pascal, e quando se pensa nas diversas concepções que estes três pensadores possuem da finitude, da fratura e da centralidade da existência humana, se compreenderá facilmente quais pressupostos teóricos dividem e, juntos, unem, os três troncos principais do existencialismo (). ${ }^{5}$

Tal tese é muito importante não apenas por traçar um panorama intelectual das origens do existencialismo, mas igualmente, por apontar um pressuposto: os três principais ramos do existencialismo. Pareyson ainda abordará um pouco do existencialismo na Itália e - em grau muito menor - até mesmo na Espanha e nos países de fala espanhola. Seu intuito é trazer a reflexão de alguns pensadores profundamente identificados com os temas da religião cristã, notadamente um cristianismo trágico e agônico como, por exemplo, o espanhol Miguel de Unamuno.

\footnotetext{
${ }^{3}$ PAREYSON, Studi sull'esistenzialismo, 2001, p. 35-36.

${ }^{4}$ Um ótimo exemplo nesse sentido é o livro de Pareyson sobre Dostoievski, dentre tantas outras menções à literatura igualmente presentes em seus diversos livros e artigos. PAREYSON, L. Dostoievski: filosofia romance e experiência religiosa, Edusp, São Paulo, 2012.

${ }^{5}$ PAREYSON, Studi sull'esistenzialismo, 2001, p. 25-26.
} 
Curiosamente, Pareyson não está sozinho na defesa de tal tipo de posição mas, ao seu lado, figura, por exemplo, o português Eduardo Lourenço, que, inclusive, interpreta o existencialismo como algo ambíguo e teológico, como se pode perceber:

Na verdade, o existencialismo contemporâneo é atravessado por duas intenções contraditórias e insanáveis. Tal como surge em Heidegger, Jaspers ou Sartre o existencialismo resulta da confluência de dois movimentos espirituais: a fenomenologia de Husserl e a filosofia da existência, ou antes a reflexão teológica sobre a existência de Sören Kierkegaard . ${ }^{6}$

A mesma Hannah Arendt que, talvez, divirja de Pareyson no que tange à popularização da filosofia proporcionada pelo existencialismo francês sartriano e de correntes correlatas, parece estar ao lado dele e de Lourenço ao perceber a importância de Kierkegaard e da reflexão religiosa no nascedouro do existencialismo e da própria filosofia moderna. Por isso, no seu texto O que é filosofia da existência lemos: "A filosofia da existência moderna começa com Kierkegaard. Não existe um único filósofo existencial que não se mostre influenciado por ele". ${ }^{7}$

Desse modo, a discussão acerca do existencialismo - e suas origens - passa a um outro patamar. Em outras palavras, Pareyson compreende o assim chamado existencialismo na rica chave da dissolução do hegelianismo o que, por sua vez, o aproxima de um pensador fundamental do seu tempo: Karl Löwith. No momento em que filósofo se debruça sobre tais teses ele - e boa parte do contexto intelectual italiano - se encontra sob forte influência de Löwith que, no seu exílio japonês na Universidade de Sendai, escreveu um dos clássicos da filosofia do século XX, a saber, a obra De Hegel a Nietzsche $e^{8}$. Ali, o chamado problema dos pós-hegelianos é visto num imenso arco onde figuram inúmeros pensadores dos mais variados matizes. Um elo comum a todos seria não apenas o obviamente cronológico, isto é, ambos estão após Hegel, mas a importante tese de que, em diferentes graus, todos apresentam um pouco da tese explorada por Pareyson da dissolução do hegelianismo. Assim, na percepção do autor italiano, pensadores como Kierkegaard e Feuerbach, por exemplo, seriam duas possibilidades ambíguas de pensamento na dissolução do hegelianismo9:

${ }^{6}$ LOURENÇO, E. Obras completas v. I - Heterodoxias [Ambiguidade do existencialismo; Situação do existencialismo], Calouste Gulbenkian, Lisboa, 2012, p. 163.

${ }^{7}$ ARENDT, H. Compreender - formação, exílio e totalitarismo, Companhia das Letras, São Paulo, 2008, p. 201

${ }^{8}$ LÖWITH, K. De Hegel a Nietzsche, Unesp, São Paulo, 2014.

Curiosamente a mesma tese apontada por Löwith é defendida por Tillich, isto é, a filosofia existencial deve ser entendida no escopo da dissolução do hegelianismo, tal como aparece em seu ensaio Significado histórico da filosofia existencial. TILLICH, P. Teologia da cultura, Fonte Editorial, São Paulo, 2009.

${ }^{9}$ Não despropositadamente Tillich nos lembra que "Feuerbach e Kierkegaard preferiram o termo 'paixão' para descrever a atitude do pensador existencial" (TILLICH, P. Teologia da cultura, 2009, p. 137). 
A ambiguidade fundamental de Kierkegard e Feuerbach em relação ao existencialismo deriva do fato que eles têm desejado conseguir uma "assimilação prática" do pensamento hegeliano, o qual concebe a filosofia como autoconsciência da realidade e da história. Kierkegaard e Feuerbach percebem que a única realização possível de tal filosofia é o "professor", e isto é o pensador abstrato, que explica a realidade que ele dissolveu no pensamento, e o pensador conciliante, que justifica o presente no qual ele concluiu a história. Nasce a crítica da "filosofia absoluta" compreendida como "professor absoluto". ${ }^{10}$

Assim percebemos quão rica se demonstra a tese pareysoniana da filosofia como assimilação prática e a sua crítica à figura do professor como o defensor do abstrato em filosofia. Aqui, quiçá, cabe mais uma aproximação com a autora que compreendeu o existencialismo em um patamar tão importante quanto aquele traçado por Pareyson: a já citada Hannah Arendt, que claramente defendeu, em seus ensaios sobre o existencialismo, tal concepção ao lado daquilo que ela denominou filosofia da vida (Lebensphilosophie) $^{11}$. Neste ponto particular, como vimos, a filósofa parece ter sido menos dura com o chamado existencialismo cultural do que foi Pareyson e não julgava impossível compreendê-lo como uma força que levava reflexões filosóficas para inúmeras pessoas, muitas delas distantes do costumeiro ambiente acadêmico.

Jon Stewart chega a apontar que Kierkegaard, tomado sempre como uma espécie de "pai do fundador do existencialismo", possui uma relação forte com a Lebensphilosophie mencionada por Arendt e, inclusive, este seria um dos motivos do seu apreço pela filosofia dos antigos em detrimento aos modernos: "Este Kierkegaard entendia filosofia como Lebensphilosophie e, portanto, tem mais em comum com os antigos do que com os filósofos modernos, o que é evidenciado por diversos caminhos" ${ }^{12}$

Luigi Pareyson se encontra profundamente influenciado, quando escreveu seus trabalhos sobre o existencialismo, por um filósofo italiano que, infelizmente, é menos conhecido entre nós. Trata-se de Franco Lombardi que, nos anos 30 do século passado, escreveu duas excelentes obras. Uma sobre Kierkegaard e outra sobre Feuerbach ${ }^{13}$. Nas duas abordagens compreende ambos os autores como produtos da dissolução do hegelianismo o que,

\footnotetext{
10 PAREYSON, Studi sull'esistenzialismo, 2001, p. 52.

11 Tal tese aparece claramente nos textos $O$ que é filosofia da existência, $O$ existencialismo francês e S. Kierkegaard, contidos no seguinte volume: ARENDT, H. Compreender: formação, exílio e totalitarismo, Companhia das Letras, São Paulo, 2008.

Também Paul Tillich explora tal coisa como uma das modalidades da filosofia da existência no seu ensaio Significado histórico da filosofia existencial: TILLICH, P. Teologia da cultura, 2009. 12 STEWART, J. Idealism and Existentialism - Hegel and the Nineteenth and - Twentieth-Century European Philosophy, Continuum, London, 2010, p. 90.

${ }^{13}$ LOMBARDI, Franco, Feuerbach, Nuova Italia, Firenze, 1935.
} Kierkegaard, Nuova Italia, Firenze, 1936. 
como se pode perceber, foi claramente adotado por Pareyson em suas teses. Além disso, tanto Pareyson como Lombardi estão em franco diálogo com as teses do já mencionado Karl Löwith. Aliás, diga-se passagem que Löwith é um pensador muito apreciado, traduzido e comentado em contexto italiano até os dias atuais. Uma prova disso são, além das inúmeras traduções de suas obras, os comentários de Orlando Franceschelli e Enrico Donaggio ${ }^{14}$.

O existencialismo em Pareyson é claramente herdeiro da dissolução do hegelianismo. Tal herança certamente é muito ampla e legitima atualmente uma gama de inúmeras concepções filosóficas. $\mathrm{O}$ que nos interessa aqui perceber é que tal como o arco de Löwith, que é muito extenso para abordar o que seria um pensador pós-hegeliano, o arco de Pareyson não é menos extenso para que possamos compreender o que é um pensador existencialista. Assim, o primeiro risco que se corre em tal tentativa de definição já está posto.

Entretanto, uma tese pareysoniana parece ressoar por toda a sua obra: o existencialismo por ser fruto da dissolução do hegelianismo apresenta uma ambiguidade também presente no próprio hegelianismo, isto é, uma típica herança do idealismo, a saber, o problema da subjetividade que, no idealismo, parece trazer além dos problemas típicos que o idealismo herda da modernidade e das discussões metafísicas e ontológicas, a pergunta por sua base teórica que, a rigor, é originária da herança grega e do cristianismo.

No enorme panorama traçado por Pareyson do idealismo alemão, vemos que a sua base está em Kierkegaard que, é claro, teria também influenciado outros pensadores do existencialismo, inclusive, para além do contexto germânico. Contudo, como sabemos pela tradição filosófica, o pensador dinamarquês é considerado, para o bem e para o mal, uma espécie de "pai fundador" do existencialismo do século XX. Assim, um ponto nos parece evidente: o existencialismo advém de uma matriz religiosa cristã como haviam pensado Pareyson e Lourenço, que, inclusive, aqui percebe a filiação do existencialismo a Kierkegaard com imensa clareza:

Não é por acaso que o seu iniciador é um teólogo. É pouco importante verificar que muitas das formas actuais da filosofia da existência têm um caráter ateísta. A sua motivação oculta continua sendo de carácter religioso e quem não puder aceitar este modo de ver, com dificuldade poderá aceder a uma exacta compreensão do existencialismo. ${ }^{15}$

${ }^{14}$ FRANCESCHELLI, O. Karl Löwith - le sfide della modernità tra Dio e nulla, Donzelli, Roma, 1997.

DONAGGIO, E. Una sobria inquietudine - Karl Löwith e la filosofia, Feltrinelli, Milano, 2004.

${ }^{15}$ LOURENÇO, Heterodoxias , 2012, p. 235. 
Paul Tillich em seu texto Significado teológico do existencialismo e da psicanálise pinta, com cores ainda mais fortes e vivas, a raiz teológica do existencialismo e, inclusive, a coloca, supreendentemente, no século XIII:

A motivação básica do existencialismo e da psicanálise surge contra o protesto cada vez maior da filosofia da consciência na sociedade industrial moderna. Esse conflito já existia antes. Apareceu no século 13 no conhecido conflito entre o primado do intelecto em Tomás de Aquino e o da vontade racional em Duns Scotus. Os dois eram teólogos. ${ }^{16}$

Desse modo, é aqui que a tese de Pareyson parece afirmar o seu potencial polêmico com o existencialismo ateu do século XX. Num texto muito conhecido entre nós denominado O Existencialismo é um humanismo, Sartre afirma categoricamente que todo autêntico existencialismo deveria ser ateu, ainda que julgue que não é o próprio ateísmo a parte principal daquilo que ele toma como um existencialismo humanista:

O existencialismo não é tanto um ateísmo no sentido em que se esforçaria por demonstrar que Deus não existe. Ele declara, mais exatamente: mesmo que Deus existisse nada mudaria; eis nosso ponto de vista. Não que acreditemos que Deus exista, mas pensamos que o problema não é o da sua existência; é preciso que o homem se reencontre e se convença de que nada pode salvá-lo dele próprio, nem mesmo uma prova válida da existência de Deus. Nesse sentido, o existencialismo é um otimismo, uma doutrina da ação, e só por má-fé é que os cristãos, confundindo o seu próprio desespero com o nosso, podem chamar-nos de desesperados. ${ }^{17}$

Parece-nos que Pareyson não concordaria com tal tese, ao menos não na sua integralidade, pois, para sua concepção, a discussão sobre a existência divina também não seria o ponto central. Contudo, ele buscaria compreendê-la em contexto ampliado como o fez, inclusive, dialogando com a fenomenologia e com o tema do eu desde a sua herança idealista. Não fortuitamente, os primeiros escritos de Pareyson sobre existencialismo aparecem novamente reafirmados, agora em outra hermenêutica, muito influenciada por Schelling ${ }^{18}$, notadamente no seu último escrito denominado Ontologia da liberdade ${ }^{19}$, sobre o qual trataremos no tópico segundo do nosso artigo. Nesse sentido, Paul Tillich talvez tenha razão quando percebeu não apenas em Kierkegaard, mas em Schelling, o percurso da filosofia da existência entre os germânicos:

\footnotetext{
16 TILLICH, Teologia da cultura, 2009, p. 163.

${ }_{17}$ SARTRE, J.P. O existencialismo é um humanismo (Os Pensadores), Abril Cultural, São Paulo, 1987, p.22

${ }^{18}$ A enorme influência de Schelling é bem percebida no artigo de Paulo Afonso de Araújo. ARAÚJO, P.A. Filosofia e experiência religiosa em Luigi Pareyson, leitor de Schelling In Numen, Juiz de Fora, v. 7, n. 2, 121-136: https://periodicos.ufjf.br/index.php/numen/article/view/21626 Acessado em 30.07.2020.

${ }^{19}$ PAREYSON, L. Ontologia da liberdade - o mal e o sofrimento, Loyola, São Paulo, 2017.

Utilizaremos a tradução brasileira em nossa análise no segundo tópico do presente artigo.
} 
A maneira especial de se fazer filosofia chamada agora de Existenzphilosophie ou "filosofia existencial" surgiu na República de Weimar como uma das principais correntes alemãs do pensamento contando entre seus líderes homens como Heidegger e Jaspers. Mas sua história remonta há, pelo menos, um século, na década de 1840 quando suas principais ideias foram formuladas por pensadores como Schelling, Kierkegaard e Marx..." ${ }^{20}$

Afirmar que o existencialismo possui um fundo religioso não significa, obviamente, negar a possibilidade de um existencialismo ateu ou agnóstico. O próprio Pareyson afirma categoricamente que três pensadores parecem centrais ao problema do existencialismo em contexto alemão. O teólogo Karl Barth ${ }^{21}$ e os filósofos Karl Jaspers e Martin Heidegger. Curiosamente um vem do campo da teologia, outra do campo da psiquiatria e outro da filosofia:

Em 1919 sai Römerbrief de Karl Barth e a Psychologie der Weltanschauungen de Karl Jaspers. Dois autores bem diferentes: de uma parte, o teólogo Barth, com o seu comentário sobre A Carta aos Romanos de São Paulo, lança as bases da teologia dialética e da teologia da crise, que tantas influências exerceram no mundo protestante, não apenas alemão, mas também francês. De outra parte, Jaspers, que de psiquiatra tornou-se psicólogo, inicia-se aquela crise de pensamento que o levará à filosofia... $\mathrm{O}$ ano de 27 pode-se considerar como a segunda etapa da história do existencialismo, porque marca a publicação de Sein und Zeit de Martin Heidegger e do Journal métaphysique de Gabriel Marcel. ${ }^{22}$

Passemos agora ao problema da relação entre ser e liberdade, aspecto central da reflexão existencialista, através de uma leitura de aspectos da Ontologia da Liberdade de Pareyson.

\section{O tema da liberdade na Ontologia da Liberdade}

A primeira parte da obra Ontologia da Liberdade é constituída por quatro lições dadas por Pareyson em Napoli em 1988 e coletadas por Aldo Magris e Francesco Tomatis. A primeira delas é sobre o tema liberdade e situação, a segunda sobre liberdade e transcendência, a terceira sobre liberdade e negação e a última sobre liberdade e dialética. Vejamos agora alguns aspectos de cada uma delas.

\footnotetext{
${ }^{20}$ TILLICH, P. Teologia da cultura, 2009, p. 123.

${ }^{21}$ Pareyson é um leitor muito atento de Karl Barth e, curiosamente, a ele dedica, inclusive em número de páginas, a maior parte de suas reflexões sobre o existencialismo germânico em sua obra Studi sull'esistenzialismo. Um excelente trabalho sobre tal relação foi escrito por Bellocci: BELLOCCI, A. Implicanza degli opposti, aporia dell'identico - Luigi Pareyson interprete di Karl Barth, Lithos, Roma, 2012.

${ }^{22}$ PAREYSON, Studi sull'esistenzialismo, 2001, p. 11.
} 
Logo de saída, a primeira lição começa exatamente com o problema da liberdade e o afirma como um problema central da filosofia moderna: “O problema da liberdade é um problema central, diria característico da filosofia moderna, a começar por Descartes, de fato, a filosofia moderna se caracteriza desse modo porque pela primeira vez afronta verdadeiramente o problema da liberdade. ${ }^{23} \mathrm{O}$ juízo parece, a princípio, positivo, entretanto, segundo nosso autor, a filosofia moderna não o leva totalmente adiante e foi impedida de tal coisa por alguns obstáculos tais como a visão mecanicista e o racionalismo.

Pareyson chega aqui a citar tanto Espinosa como Hegel e o conceito de libera necessitas, isto é, a necessidade livre. Trata-se de algo muito ligado ao conceito de necessidade, algo que deve ocorrer de modo necessário e, assim, quiçá se estabelece o primeiro embate com a ideia de liberdade ou algo voluntário. Tal questão nunca foi efetivamente resolvida e retorna na chamada dissolução do hegelianismo, ou seja, com Kierkegaard e outros dos autores pós-hegelianos.

Cabe mencionar aqui um intrigante aspecto biográfico do autor que, a despeito da curiosidade pessoal, implica no seu fazer filosófico e aponta importantes pistas para a reconstrução das suas interlocuções e debates: "É natural que eu, formado no existencialismo, considerasse como central o problema da liberdade". ${ }^{24}$ Após tal afirmativa, ele reconstrói um pouco de sua trajetória filosófica nos primeiros anos de estudos e cita alguns de seus mestres em contexto italiano e também algumas das possibilidades do seu pensar filosófico que, advinda da herança hegeliana - e da dissolução do hegelianismo- deparou-se com opções como Kierkegaard e Feuerbach, dentre outras.

Para além destes dois autores, uma outra opção foi feita pelo filósofo: estudar o conceito da liberdade em Fichte e igualmente em Schelling. A escolha parece ter seus motivos. Se de um lado, como herdeiro dos pós-hegelianos, Feuerbach e Kierkegaard representam a crítica ou a dissolução do hegelianismo, Fichte e Schelling mostram ao autor a possibilidade da dissolução do sistema por quem havia ajudado a construí-lo: "Só quem havia participado da construção da filosofia hegeliana podia colaborar para dissolvê-la. ${ }^{25}$ Contudo, o ponto mais importante aqui é exatamente que, no seu entender, ambos ajudavam na tentativa de reconstruir uma filosofia da liberdade. Paul Tillich parece ter razão quando, tal como Pareyson, escolhe Schelling como um autor central para aqueles que se aventuram na chamada filosofia da existência e nisso nos ajuda a melhor perceber também as escolhas do pensador italiano: “Eu, pessoalmente, estava

\footnotetext{
${ }^{23}$ PAREYSON, Ontologia da liberdade, 2017, p. 27.

${ }^{24}$ PAREYSON, Studi sull'esistenzialismo, 2001, p. 28.

${ }^{25}$ PAREYSON, Ontologia da liberdade, 2017, p. 28-29.
} 
preparado de uma forma tríplice para aceitar esta filosofia. Em primeiro lugar, por ter um conhecimento do período final de Schelling, em que ele tentou, em oposição à filosofia do ser de Hegel, abrir um caminho para a filosofia da existência". ${ }^{26}$

Aqui vale a pena estarmos atentos para quão significativa - e filosoficamente rica- é a explicação do plano das quatro aulas segundo o próprio Pareyson:

Para quem me segue, portanto, estas aulas serão um contato não apenas comigo que sou pouca coisa, mas sobretudo com estes autores, sob a insígnia de uma filosofia da liberdade: Plotino, Pascal, Fichte, Kierkegaard, Schelling, o existencialismo é todo um programa, tanto teórico quanto histórico, pois é toda uma nova historiografia filosófica que se desenha a partir desse ponto de vista, e é toda uma nova problemática na qual os conceitos centrais são existência, pessoa, interpretação e, sobretudo, liberdade..$^{27}$

Assim, diante da relevância do existencialismo e suas questões filosóficas, surge a pergunta sobre o que Pareyson toma por situação, visto que este será o objeto da primeira lição. Sua definição parece ser a de Max Scheller, ou seja, o lugar do homem no cosmos é o ponto central, "não apenas sua colocação histórica, mas também sua colocação ontológica". ${ }^{28}$

O homem é uma relação consigo mesmo e com o outro. Portanto, temos aqui dois termos e, em ambos, a relação envolve o ser. A tese instigante de Pareyson a ser explorada consiste exatamente numa recusa da ontologia tradicional, que sempre parte inicialmente de uma discussão sobre o ser. Segundo o pensador, o fundamento é a liberdade e não o ser. Desse modo, o objetivo das lições fica patente: "Como veremos melhor na sequência, o ser não é fundamento, e por que isso? Porque, como veremos, é liberdade. Aqui há o repúdio da metafísica ôntica, objetiva, especular, a favor de uma ontologia crítica, que fala do ser apenas indiretamente".$^{29}$

No entender do pensador, o homem é relação, consciência real, tal como se pode perceber nas reflexões de Kierkegaard na Doença Mortal e nos escritos de Heidegger e de Gabriel Marcel. O jogo pareysoniano consiste, portanto, numa auto-relação (interna de cada homem consigo mesmo) e numa hetero-relação (externa e feita com um outro).

Se as coisas da liberdade parecem ocorrer no campo das escolhas, resta, então, a pergunta: o que existe de necessário em nós? Quiçá podemos elencar aqui características genéticas, culturais, finitude, etc. Na liberdade, vista como o domínio da escolha e do contingente, tudo pode ser dife-

${ }^{26}$ TILLICH, P. No limite, Fonte Editorial, São Paulo, 2016, p. 66. As duas outras menções de autores feitas por Tillich são Kierkegaard e Heidegger, mas não as desenvolveremos aqui.

${ }^{27}$ PAREYSON, Studi sull'esistenzialismo, 2001, p. 29.

${ }^{28}$ PAREYSON, Studi sull'esistenzialismo, 2001, p. 29.

${ }^{29}$ PAREYSON, Ontologia da liberdade, 2017, p. 30. 
rente do necessário. Contudo, de modo paradoxal, a liberdade também possui condicionantes e, desse modo, as escolhas não são absolutas como se imagina.

Antes de mais nada, a liberdade é atividade. A liberdade é dada, mas é também consciência. Por isso, "não é possível recebê-la senão já a exercitando". ${ }^{30}$ Em outras palavras, há uma dialética da liberdade. Ela é pensada e recebida, mas, ao mesmo tempo, é também ação. Curiosamente, "o ato de exercitá-la não é posterior ao ato de recebê-la" (Pareyson, 2017, p. 34) e nisso consiste a sua riqueza. Em tal dialética da liberdade, Pareyson aponta ainda aspectos de dom e de consenso. O jogo liberdade contrastando com necessidade é ultrapassado na medida em que, na interpretação do filósofo, o dom é "um dom de 'mim' a 'mim". ${ }^{31}$

Desse modo, não é interesse do pensador abordar o tema da liberdade pura. Certamente trata-se de um tema complexo da história do pensamento e que merece toda a atenção. Entretanto, o interesse reside aqui em ir do embate entre liberdade e necessidade tradicional para agora perceber como ocorre o embate da liberdade com a própria liberdade. Aqui reside a complexa discussão entre liberdade e ser aos olhos de Pareyson.

A atividade humana é constituída por dois pontos centrais: fidelidade ao ser e compromisso da liberdade. Em tal contexto, Pareyson apresenta sua tese forte da exposição: a liberdade ilimitada, pois, no seu entender, "ou a liberdade é ilimitada ou não é". ${ }^{32} \mathrm{~A}$ fim de desenvolver melhor tal tese seria preciso, antes de qualquer coisa, esclarecer a possível "confusão" entre ser e liberdade, isto é, sincronizá-los. Por isso, o filósofo tentará reinterpretar tanto o tema da liberdade pura (lendo criticamente a ontologia tradicional) e igualmente problematizará o tema das escolhas e das contingências, como o faz uma postura mais ligada aos temas clássicos do existencialismo. Assim, o tema do abismo lhe parece tão fascinante: "A liberdade é um abismo, uma profundidade sem fim, e aqui é preciso afirmar o princípio da indivisibilidade da liberdade" ${ }^{33}$ Escolhido tal caminho, o filósofo depara-se com o aspecto religioso da questão e por isso necessitará construir, a partir da segunda lição, uma nova hermenêutica e novos significados para uma melhor investigação do tema da liberdade e do ser.

Em que consiste, então, a nova hermenêutica do mito? Antes de chegar a desenvolver a pergunta propriamente dita, Pareyson dedica-se a um breve comentário sobre mito e pretende percebê-lo como "uma experiência existencial da realidade".$^{34}$ Assim, parece que temos um foco mais preciso do

\footnotetext{
${ }^{30}$ PAREYSON, Ontologia da liberdade, 2017, p. 34.

${ }^{31}$ PAREYSON, Ontologia da liberdade, 2017, p. 35.

32 PAREYSON, Ontologia da liberdade, 2017, p. 37.

${ }^{33}$ PAREYSON, Ontologia da liberdade, 2017, p. 39.

${ }^{34}$ PAREYSON, Ontologia da liberdade, 2017, p. 41.
} 
que discutir mito na sua amplitude como história, realidade, narrativa e, em todos esses casos, como algo oposto ao racional. Logo, o intuito é uma aproximação existencial da religião, percebendo o quanto uma narrativa é, na verdade, diferente de uma mentira vista em stricto sensu.

Assim, seu objetivo não é trocar mythos por logos e ainda menos entrar em um tema que foi tão caro a vários autores pós-hegelianos, a saber, a discussão sobre desmitologização ou demitificação. No seu entender, o mito não pode - e não deve ser traduzido em forma filosófica- "pois a transposição filosófica deformaria o mito".$^{35} \mathrm{O}$ mito não explica ou define Deus, mas sua hermenêutica percebe em que implica sua crença. Logo, o interesse volta-se para aquilo que aponta a nova hermenêutica. "A tarefa da hermenêutica do mito é esclarecer o sentido e universalizar o mito". ${ }^{36}$ Em outras palavras, é preciso uma nova hermenêutica exatamente para lidar com o problema do sentido. Este parece ser doravante o ponto central de tal posicionamento. A universalização só pode vir depois desse primeiro passo executado.

Surge, então, um debate entre prática e experiência que, segundo o filósofo, já estava presente em Hegel e Schelling. O mito inevitavelmente depara-se com um problema insolúvel, que é igualmente insolúvel para a filosofia desde os tempos mais remotos: o problema do mal, espécie de "beco sem saída" para ambos. Pareyson parece ver aqui o diálogo com a religião na chave de um diálogo com a experiência religiosa e, por isso, precisa de uma nova hermenêutica para tanto, visto que não se trata de compreender a religião conceitualmente. A filosofia deve superar, também aqui o jogo de oposição entre liberdade e necessidade e o problema da teodiceia para chegar a tal posicionamento. Aliás, nesse sentido, Pareyson não nutre grandes esperanças sobre o que pode realizar a filosofia em tal terreno: "Para o mal, a filosofia jamais ultrapassa, ou dificilmente ultrapassará, o problema da teodiceia...". ${ }^{37}$

A experiência religiosa coloca o tema da liberdade com vigor e maior ênfase que a filosofia. Por isso, Pareyson deseja colocar-se em tal ponto para o debate. Contudo, devemos aqui fazer um esclarecimento. $O$ filósofo não toma a experiência religiosa como algo estritamente da esfera privada ou daquilo que convencionamos chamar de subjetivo. Ainda que ela envolva - ou possa envolver seres particulares - o que interessa é que, por seu intermédio, pode-se perceber a liberdade como ato puro em Deus, isto é, aquele que age para evitar a necessidade. Nisso reside, por exemplo, a temática do Gênesis. Desse modo, cabe talvez recordar, notadamente nas últimas linhas da primeira lição, o que nos diz o filósofo sobre experiência

35 PAREYSON, Ontologia da liberdade, 2017, p. 42.
36 PAREYSON, Ontologia da liberdade, 2017, p. 42.
37 PAREYSON, Ontologia da liberdade, 2017, p. 43. 
religiosa: “... porque a experiência religiosa (a consciência religiosa) faz parte, em conjunto com a arte, com o pensamento originário...". ${ }^{38}$

O homem é responsável por seus atos, ainda que não seja o autor da sua própria liberdade. A responsabilidade humana reside no ato e, em Deus, ela é plena e, inclusive, pode ser arbitrária, se é que se pode aplicar tal conceito à divindade sem cairmos no mesmo problema do racionalismo da teodiceia. Assim antes, de examinar o problema da liberdade em Deus, Pareyson julga mais apropriado perceber o tema da liberdade no homem. "Gostaria de examinar a liberdade humana como início, como início puro, como começo absoluto, para ter então o modo de definir de maneira mais precisa a liberdade originária em sua ilimitação e em sua absoluta e soberana arbitrariedade". 39

Para tanto, Pareyson toma a situação como um evento, algo sobre o qual não sabemos precisar exatamente o aparecimento e nem os desdobramentos. Algo em si e para si. Algo que aparece e desaparece. Assim seria a liberdade no seu entender: começaria do nada. "A liberdade começa a partir do nada: o nada da liberdade. É um puro início no vazio de tudo. O ato de liberdade (um evento, um fato da liberdade) é um ato de escolha ao qual nada preexiste".${ }^{40}$ Curiosamente, a mesma definição de nada encontra-se, em modo muito semelhante, nas reflexões de Kierkegaard no Conceito de angústia, onde o nada não alcança precisão conceitual, a despeito de ser reconhecido como sentimento angustiante:

Neste estado há paz e repouso, mas ao mesmo tempo há algo de diferente que não é discórdia e luta; pois não há nada contra o que lutar. Mas o que há, então? Nada. Mas nada, que efeito tem? Faz nascer angústia. Este é o segredo profundo da inocência, que ela ao mesmo tempo é angústia. Sonhando o espírito projeta a sua própria realidade efetiva, mas esta realidade nada é, mas este nada a inocência vê continuamente fora dela. ${ }^{41}$

Talvez seja desnecessário pontuar o quanto tal conceito será igualmente importante nas reflexões da filosofia da existência, por exemplo, em autores como Heidegger e Sartre, bem como no chamado niilismo nietzschiano enquanto tradição filosófica fundante e a partir do qual, juntamente com as reflexões de Dostoievski hoje fala-se em corrente niilista ${ }^{42}$.

Com o intuito de melhor ilustrar o problema do nada, Pareyson faz menção ao conto de Isaac Bashevin Singer sobre o judeu que trai a esposa com a cunhada. Assim, aquele homem devoto e pio de horas antes, agora é o

\footnotetext{
${ }^{38}$ PAREYSON, Ontologia da liberdade, 2017, p. 40.

${ }^{39}$ PAREYSON, Ontologia da liberdade, 2017, p. 45.

${ }^{40}$ PAREYSON, Ontologia da liberdade, 2017, p. 46.

${ }^{41}$ KIERKEGAARD, S.A. O Conceito de angústia, Vozes, Petrópolis, 2010, p. 45.

${ }^{42}$ Importante referência para percebemos tal reflexão é o livro de Karl Löwith:

LÖWITH, K. Il Nichilismo europeo, Lateza, Roma, 1999.
} 
mesmo homem cheio de culpa e depravação: "Menos de duas horas antes, Reb Mendel ainda era um judeu honesto, eminente; agora um depravado, um traidor de Deus. ${ }^{43}$ Desse modo, a mudança veloz da condição de santo para pecador é o que nos interessa aqui observar. Ou seja, a liberdade é precedida pelo nada. No dizer de Pareyson: "a liberdade não é precedida senão pela própria liberdade" ${ }^{44} \mathrm{O}$ nada e o vazio, portanto, orbitam em torno à liberdade.

Há ainda uma outra característica da liberdade: ela é irrevogável. Tempo e memória merecem aqui ser vistos com cuidado. O "antes" e "depois" tornam-se fundamentais, mas, ao mesmo tempo, podem mudar velozmente. Em outras palavras, um evento que poderia ter ocorrido antes, talvez não possa mais agora ocorrer. As condições são outras, ainda que os personagens possam ser os mesmos. Curiosamente, tal relação com o tempo e com a ideia de evento apresentada por Pareyson pode nos remeter a uma importante observação feita por Tillich acerca do tempo cronológico e do conceito de chronos, tal como pensado pelos gregos:

A extrema sensibilidade do espírito da língua grega diferenciou chronos, tempo formal, de kayros, 'tempo certo' ou momento pleno de riqueza de conteúdo e de significado. Não foi por acidente que esta palavra veio a ser empregada com frequência e força quando a língua grega se tornou o meio de comunicação do espírito dinâmico do judaísmo e do cristianismo primitivo, no Novo Testamento. ${ }^{45}$

Na percepção de Pareyson a semelhança entre o homem e Deus reside na liberdade: "Como o homem não é senão liberdade e nisso é a imagem de Deus, de modo que Deus não é senão liberdade, e absolutamente livres e arbitrários são todos os seus atos, mas precisamente seu ato inicial de autocolocação". ${ }^{46}$ Aqui o filósofo explora as passagens bíblicas como acontecimentos e eventos e não como fatos históricos, como talvez o tenha feito a crítica bíblica dos séculos XIX e XX e uma certa tentativa de harmonização entre teologia e filosofia. Assim, mesmo com a devida distinção, o filósofo italiano talvez pudesse compartilhar o juízo do teólogo Paul Tillich, quando este pensa num tipo de aproximação entre filosofia e teologia muito mais significativa na esfera existencial: "Para esclarecer, não é a filosofia que inclui a resposta teológica e a explica filosoficamente. Tal empresa seria idealismo, e, portanto, o oposto da filosofia da existência. No entanto, a filosofia da existência faz a pergunta de uma maneira nova e radical, cuja resposta é dada na teologia pela fé". ${ }^{47}$

${ }^{43}$ PAREYSON, Ontologia da liberdade, 2017, p. 46.

${ }^{44}$ PAREYSON, Ontologia da liberdade, 2017, p. 46.

${ }_{45}$ TILLICH, P. A Era protestante, Metodista, São Bernardo do Campo, 1992, p. 64.

${ }^{46}$ PAREYSON, Ontologia da liberdade, 2017, p. 49.

${ }^{47}$ TILLICH, P. No limite, 2016, p. 66. 
Nesse sentido, a definição do Deus do Antigo Testamento, que categoricamente afirma "Eu sou o que sou" é uma rica tese a ser explorada. Ela mora na fronteira com o indizível, com aquilo que não se pode definir. Assim, Deus antes de Deus é abissal. Por isso, o próprio esforço de Pareyson parece aqui limitado: "Acima de tudo isso que estou dizendo e estou para dizer são só esforços inadequadíssimos para poder aludir, de algum modo, ao inefável, ao indizível, porque estamos no ápice das possibilidades mesmas da especulação". 48

Pareyson toma a presença divina como o maior dos eventos: "E essa irrupção de Deus na realidade, é uma vitória sobre o nada. ${ }^{49}$ Assim, a questão da liberdade humana e liberdade divina é um falso dilema para sua leitura, que parte do ponto de vista religioso: "Do ponto de vista religioso, jamais poderá ocorrer um contraste entre a liberdade divina e a liberdade humana a não ser por vontade da liberdade humana, que se opõe a Deus..."..$^{50}$

Ele refuta ainda a tese da presciência divina no Gênesis. No seu entender o ato criador está intrinsicamente relacionado com a própria liberdade. Por isso ele prefere não dizer que Deus "prevê", mas que Deus "vê", postando-se ao lado do homem e não como observador científico: "A efetiva escolha do homem não é prevista, mas é vista. Não tem nenhum sentido o 'pre'- : é vista quando o homem a faz, e, é vista em sua intemporalidade. Não é pré-ciência, mas é ciência contemporânea, é ciência intemporal; o saber divino é contemporâneo ao agir humano". ${ }^{51}$

Do mesmo que a presciência não existe do ponto de vista religioso, a necessidade é uma ilusão segundo o filósofo. Por isso, a relação entre Deus e homem é sempre um exercício da liberdade que, ora parece esbarrar na presciência, ora parece tomar a liberdade como ilusória e enfatizar a necessidade. Contudo, o que parece mesmo importante é a própria liberdade.

Deus continua a correr o risco da liberdade humana, continua a demandar sua colaboração, e para isso conta com a indivisibilidade dessa liberdade. E o homem continua a interromper-lhe o curso, ou para recuperar o nada inicial da liberdade em sentido positivo, ou para ser também ele Deus; e aqui ou realizando em si sua imagem divina ou rebelando-se para substituir Deus pela própria liberdade. É nesse acontecimento o grande mistério da existência como coincidência de autorrelação e heterorrelação. ${ }^{52}$

Assim todas estas questões parecem, no fundo, também nos remeter ao problema da liberdade e da negação, temas centrais para todo o existencialismo do século XX. Se aos olhos do filósofo, a liberdade possui um

\footnotetext{
${ }^{48}$ PAREYSON, Ontologia da liberdade, 2017, p. 51.

${ }^{49}$ PAREYSON, Studi sull'esistenzialismo, 2001, p. 52.

${ }^{50}$ PAREYSON, Ontologia da liberdade, 2017, p. 54.

${ }^{51}$ PAREYSON, Ontologia da liberdade, 2017, p. 55.

${ }^{52}$ PAREYSON, Ontologia da liberdade, 2017, p. 55.
} 
início absoluto e, de igual modo, deve ser lida na chave de uma relação com a transcendência, agora a liberdade afirma-se aqui como escolha, isto é, como ato da vontade humana. A escolha se dá sempre entre opções disponíveis e seria equivocado querer avançar para além disso ou, então, idealização infrutífera, que em nada resultaria.

A questão central parece então ser a questão do ser e do não ser; do bem e mal. O ser livre é a escolha e se constitui na passagem do não ser para ser. A liberdade positiva e liberdade negativa aparecem aqui, portanto, lado a lado. Até mesmo a negação da liberdade é, na realidade, constituída por um ato livre. O homem que, na famosa máxima de Sartre está "condenado a ser livre" não deixa de ter aqui o seu sentido. Por isso, não querer ver é também uma posição, um ato. No entender de Pareyson, o não ser somado à Liberdade resulta no Nada e o não ser somado à escolha resulta no mal. Em outras palavras, a liberdade negativa é a primeira fase da liberdade humana, ou seja, aquela que opta voluntariamente pelo mal. Já á liberdade positiva equivale a uma vitória sobre o mal e, também por isso, sobre o nada. Logo, ela só pode ser plenamente alcançada em Deus.

Vale aqui nos determos um pouco mais na explicação. Há, na filosofia de Pareyson, um conceito teológico por trás da liberdade negativa, isto é, dessa escolha humana que sempre ocorre pelo mal, havendo nele também pressupostos para tanto. De igual modo, há um conceito teológico por trás da liberdade positiva, isto é, desse Deus que escolhe sempre o bem e também nele há pressupostos para afirmar tal tese. Assim, surgem algumas dúvidas: a) Deus poderia escolher o mal, visto que ele é bom?; b) $\mathrm{O}$ homem poderia escolher o bem, visto que ele é mau? Aqui, tal coisa já não parece mais ser possível. Kierkegaard fornece um ótimo exemplo disso nas Migalhas filosóficas onde, ao discutir o tema do livre-arbítrio, isto é, do jogo entre liberdade e não-liberdade, liberdade positiva e liberdade negativa, a compara com um garoto numa loja onde podia comprar um brinquedo ou um livro mas, ao eleger o brinquedo, não pode voltar no dia seguinte arrependido e trocá-lo pelo livro:

Se um menino tivesse recebido de presente uma pequena soma de dinheiro e então com isso pudesse comprar, por exemplo, um bom livro ou um brinquedo, já que as duas coisas teriam o mesmo preço, caso ele comprasse o brinquedo, poderia ainda, com o mesmo dinheiro, comprar o livro? De maneira nenhuma, pois aí o dinheiro já teria sido gasto. Mas talvez ele pudesse dirigir-se ao livreiro e perguntar-lhe se este não ficaria com o seu brinquedo, dando em troca o livro. Suponhamos que o livreiro respondesse: 'Meu querido menino, o teu brinquedo não tem nenhum valor, é bem verdade que naquela ocasião em tinhas o dinheiro tanto podias comprar o livro quanto o brinquedo; mas com o teu brinquedo acontece algo singular; pois logo depois de comprado perde todo o seu valor. ${ }^{53}$

${ }^{53}$ KIERKEGAARD, S. A. Migalhas filosóficas, Vozes, Petrópolis, 1995, p. 36, nota 10. 
Há aqui ainda um aspecto singular a ser notado: no entender de filósofo italiano não existem, a rigor, duas liberdades, isto é, a negativa e a positiva. Trata-se, na realidade, de uma liberdade única com suas ambiguidades: "Há liberdade positiva e negativa, mas de fato não são duas liberdades, mas uma só, que pode ser positiva ou negativa. A liberdade é única, mas dúplice e ambígua...". ${ }^{54}$ A partir do foco na duplicidade e na ambiguidade, alcança-se o que ele denominou como "pessimismo" ou "otimismo", isto é, a liberdade negativa estaria relacionada ao "pessimismo" e a liberdade positiva ao "otimismo". Contudo, deve-se aqui ter cautela, pois a resposta não parece tão simples e imediata. No seu entender, ambas "não são categorias ontológicas, mas psicológicas e, portanto, inadequadas para dar uma representação da realidade". ${ }^{55}$ Assim, o que parece lhe interessar efetivamente é então "o pensamento trágico, que não é nem otimista nem pessimista" ${ }^{56}$ Ainda mais forte do que isso: “... porque é trágico e angustiante que o homem não possa fazer o bem a não ser com o próprio ato com o qual pode fazer o mal, e não possa chegar à alegria a não ser por meio da dor, e que com frequência a virtude floresça sobre o vício, e que a alegria não tenha outra sede que o sofrimento" ${ }^{57}$ Salta aos olhos, do leitor interessado, o quanto tal conceito de trágico do pensador italiano remonta não apenas a herança grega, mas também, aspectos centrais do cristianismo e se afirma em franco diálogo com as teses do cristianismo kierkegaardiano e do pensador espanhol Miguel de Unamuno no seu clássico Do Sentimento trágico da vida ${ }^{58}$.

Partindo da clássica discussão sobre o livre-arbítrio, que remonta certamente às teses agostinianas, o pensador italiano vai além de simplesmente apontar que o homem escolhe o mal (negativamente) e Deus escolhe o bem (positivamente). Na sua concepção, “a escolha positiva é ela mesma a escolha do bem e a escolha negativa é ela mesma a escolha do mal" ${ }^{59}$ Por isso, "o bem e o mal não preexistem à escolha, estão depois da escolha, são o bem e o mal escolhidos, começam a ser depois da escolha como escolha positiva ou negativa, como bem ou mal escolhidos" ${ }^{60}$ Investigando o espírito do Gênesis, Pareyson afirma: "No homem, a primeira escolha foi uma escolha negativa; em Deus, a primeira escolha foi positiva". ${ }^{61}$ Também Kiekegaard, no Conceito de angústia, percebe que a escolha humana, no fundo, é uma escolha pelo nada (o que Pareyson chamou aqui de negativo), pois o homem ainda parece não poder discernir o bem do

\footnotetext{
${ }^{54}$ PAREYSON, Ontologia da liberdade, 2017, p. 60.

${ }^{55}$ PAREYSON, Ontologia da liberdade, 2017, p. 61.

${ }^{56}$ PAREYSON, Ontologia da liberdade, 2017, p. 61.

${ }^{57}$ PAREYSON, Ontologia da liberdade, 2017, p. 62.

${ }^{58}$ UNAMUNO, M. Do Sentimento trágico da vida: nos homens e nos povos, Martins Fontes, São

Paulo, 2019.

${ }^{59}$ PAREYSON, Ontologia da liberdade, 2017, p. 62.

${ }^{60}$ PAREYSON, Ontologia da liberdade, 2017, p. 62.

${ }^{61}$ PAREYSON, Ontologia da liberdade, 2017, p. 62-63.
} 
mal. Em tal contexto é que se percebe efetivamente a angústia no entender do pensador dinamarquês:

Neste estado há paz e repouso, mas ao mesmo tempo há algo de diferente que não é discórdia e luta; pois não há nada contra o que lutar. Mas o que há, então? Nada. Mas nada, que efeito tem? Faz nascer angústia. Este é o segredo profundo da inocência, que ela ao mesmo tempo é angústia. Sonhado, o espírito projeta a sua própria realidade efetiva, mas esta realidade nada é, mas este nada a inocência vê continuamente fora dela. ${ }^{62}$

Contudo, devemos perceber uma coisa ainda mais, pois, segundo o pensador, a primeira escolha humana "não é por si só irreversível, mas se repetirá enquanto o homem não estiver em condições de restaurar o funcionamento da liberdade". ${ }^{63}$ Vejamos o quanto tal tese enriquece a explicação do filósofo italiano pois, a partir desse momento, podemos falar sobre as consequências da liberdade do homem (e de criação divina). Desse modo: "Da parte de Deus a criação com tudo o que dela segue, e da parte do homem, a queda com tudo o que dela segue" ${ }^{64}$

Entretanto ainda parece que as questões centrais seguem em aberto. "E se Deus tivesse escolhido o mal? E o se o homem tivesse escolhido o bem? ". ${ }^{65} \mathrm{O}$ problema central do pensador italiano é, na verdade, uma questão milenar: o livre-arbítrio que, talvez, precise aqui ser contemplado numa espécie de arco capaz de abranger desde as reflexões de Santo Agostinho no século IV até as teses kierkegaardianas já no século XIX, o que, obviamente, seria um imenso desafio. Contudo, Pareyson parece, na realidade, acreditar que a questão é mal colocada. "São problemas mal colocados, porque, de fato, tais possibilidades não aconteceram e, assim, é inútil delongar-se em seu exame...". ${ }^{66}$ Aliás, aqui o filósofo descarta a hipótese de Deus poder optar pelo mal pois, nesse caso, " o Deus mal é a inexistência de Deus". ${ }^{67}$ Por isso, de toda essa dialética, destaca-se a liberdade, que sempre convive nesse misto de coisas:

De todo modo, de toda essa análise que fiz até aqui, gostaria de demonstrar isso: que a liberdade é ao mesmo tempo poder de se originar (e assim, início absoluto), e escolha negativa ou positiva, e isso em absoluto, onde quer que haja liberdade. Em todo ponto a liberdade é indivisível, mesmo se diversa

${ }^{62}$ KIERKEGAARD, S.A. O Conceito de angústia, Vozes, Petrópolis, 2010, p. 45.

${ }^{63}$ PAREYSON, Ontologia da liberdade, 2017, p. 63.

${ }^{64}$ PAREYSON, Ontologia da liberdade, 2017, p. 63. O teólogo protestante Harvey Cox desenvolve em sua obra Que a serpente não decida por nós uma excelente reflexão a partir dos primeiros capítulos do Gênesis e, segundo sua tese principal ali exposta, o grande problema da humanidade foi exatamente não decidir, deixando a escolha para a astuciosa serpente. Quiçá se poderia pensar nisso como uma modalidade de "não escolha" ou mesmo escolha negativa. COX, H. Que a serpente não decida por nós, Civilização Brasileira, Rio de Janeiro, 1970.

${ }^{65}$ PAREYSON, Ontologia da liberdade, 2017, p. 63.

${ }^{66}$ PAREYSON, Ontologia da liberdade, 2017, p. 63.

${ }^{67}$ PAREYSON, Ontologia da liberdade, 2017, p. 64. 
em intensidade e em potência, e apresenta estas duas características: jorra impetuosamente e se divide de modo dúplice. Em todo ponto a liberdade é início e escolha. ${ }^{68}$

A afirmação de Deus é a derrota do nada e, desse modo, o mal equivale a uma possibilidade, tal como o pecado no mundo foi possível com Adão, isto é, com ele entrou no mundo, como bem lembrou Kierkegaard no Conceito de angústia, não o pecado "número um" do gênero humano, mas a pecabilidade, isto é, a possibilidade de pecar:

Com o primeiro pecado, entrou o pecado no mundo. Exatamente do mesmo modo vale isso a respeito do primeiro pecado de qualquer homem posterior, que com este pecado o pecado entra no mundo. Dizer, contudo, que não existia pecado antes do pecado de Adão, é uma reflexão não apenas inteiramente casual e sem relevância no que concerne ao pecado em si, como totalmente destituída de significado e de direito de tornar maior o pecado de Adão ou menor o primeiro pecado de qualquer outro ser humano. ${ }^{69}$

A outra ponta desta questão pode ser observada na tentativa de querer negar Deus ou querer ser Deus, como bem percebem Nietzsche e Dostoievski. Pareyson, parodiando o pensador alemão, afirma: “Diz Nietzsche que o homem não pode reconhecer Deus sem querer sê-lo: a expressão é minha, mas o conceito nietzschiano é esse" ${ }^{70} \mathrm{O}$ mesmo ocorreria, na sua visão, com o romancista russo: "Assim também em Dostoievski: o homem em seu orgulho, não pode querer ser Deus; o homem não pode reconhecer Deus sem querer colocar-se no seu lugar". ${ }^{71}$ Aqui reside o problema da revolta contra a divindade tanto em Nietzsche como em Dostoievski.

Ao se deparar, na quarta lição, com o problema da liberdade e da dialética, o filósofo afirma a originariedade da escolha que, segundo sua visão, é o problema capital de toda ontologia da liberdade. No seu entender, afirmar que Deus existe é, na realidade, dizer "foi escolhido o bem". ${ }^{72}$ Este Deus que é vence o mal e o nada. Portanto, o bem foi escolhido.

Há aqui o choque entre eternidade e história; transcendência e imanência. O conceito de queda (ou de pecado) para Pareyson é de suma importância e não fortuitamente, como pudemos ver, dialoga com as teses de Kierkegaard no Conceito de angústia. Assim, sua ontologia da liberdade é, na realidade, tributária das reflexões kierkegaardianas. Inclusive, daquelas tão bem expostas nas Migalhas filosóficas, onde o autor dinamarquês tenta construir uma possível dialética para explicar a situação do homem no mundo pós-pecado e sua possível saída com o auxílio de uma divindade,

\footnotetext{
${ }^{68}$ PAREYSON, Ontologia da liberdade, 2017, p. 64.

${ }^{69}$ KIERKEGAARD, S.A. O Conceito de angústia, Vozes, Petrópolis, 2010, p. 33.

${ }^{70}$ PAREYSON, Ontologia da liberdade, 2017, p. 67.

${ }^{71}$ PAREYSON, Ontologia da liberdade, 2017, p. 67.

72 PAREYSON, Ontologia da liberdade, 2017, p. 71.
} 
talvez representada por algum tipo de Mestre Salvador: "O mestre é então o próprio Deus que, atuando como ocasião, leva o aprendiz a lembrar-se de que é a não-verdade e que o é por sua própria culpa. Mas a este estado (o de ser a não-verdade e de sê-lo por própria culpa), que nome lhe podemos dar? Chamemo-lo de pecado. ${ }^{73}$

Também Ernst Cassirer, por um outro registro, explora o tema do pecado como fator constitutivo importante para uma melhor compreensão da filosofia moderna e, talvez, ao averiguarmos sua tese, isso nos ajude no esclarecimento da ontologia da liberdade de Pareyson, isto é, por qual motivo o tema do pecado mostra a afinidade do autor italiano com o projeto kierkegaardiano que, a rigor, se constitui como um projeto moderno oposto ao projeto da Renascença e do iluminismo clássico. Por isso, o cerne do projeto quiçá possa ter maior proximidade com o modelo protestante e sua ênfase no pecado original:

O âmago do conflito pode definir-se numa expressão: o pecado original, a propósito do qual o Humanismo e a Reforma têm posições radicalmente diferentes. O Humanismo, bem entendido, jamais ousou atacar frontalmente o dogma da queda original, mas toda a sua orientação espiritual tende a abrandar o rigor do dogma, a privá-lo de sua força". ${ }^{74}$

Há, então, um problema de fundo: a crença no final escatológico. Segundo a concepção de Pareyson o pecado humano acabou por cunhar a divisão temporal tal como a conhecemos: "Com a queda, o homem por assim dizer, dividiu a eternidade, nela inseriu uma cunha que, por um viés, levou para trás e, por outro, projetou para frente a vitória sobre o mal, prevendo-a ao mesmo tempo como um passado ou como um futuro e, no meio disso tudo, o tempo humano, a história humana. ${ }^{75}$ Assim, firma-se aqui a confiança no futuro.

No entender do filósofo italiano, o universo possui duas facetas: uma temporal e uma eterna e, desse modo, ambas estão sempre em diálogo. A partir daqui ele almeja, de certo modo, explicar, na medida em que isso é possível, a dialética divina. Entretanto, como já vimos, o pensador recusa qualquer tipo de teodiceia ou explicação nos moldes daquilo que fizeram os pensadores modernos. Seu intuito é abordar um pouco aquilo que ele denominará como dialética temporal e a luta entre o bem e o mal em tal contexto; entre positivo e negativo. Pareyson denominou isso como dialética diática e inspira-se para tal tese no filósofo francês Blaise Pascal que, a despeito de situar-se na modernidade, é um moderno deslocado do seu tempo. Por isso, parece aqui fazer sentido quando o autor italiano opõe Pascal e Hegel: "Enquanto a dialética hegeliana é de caráter conciliador, de acomodamento, pacificador, a pascaliana é anuladora, fustigante,

${ }^{73}$ KIERKEGAARD, Migalhas filosóficas, Vozes, Petrópolis, 1995, p. 35.

${ }^{74}$ CASSIRER, E. Filosofia do iluminismo, Unicamp, Campinas, 1997. p.195.

${ }^{75}$ PAREYSON, Ontologia da liberdade, 2017, p. 72. 
inquietante" (Pareyson, 2017, p. 76). Assim, se temos nos temas hegelianos a superação, que equivale à negação da negação, temos em Pascal o paradoxo que, não fortuitamente, será de singular importância também em Kierkegaard e em Pareyson. Em outras palavras, afirma-se aqui a possibilidade de coexistência de opostos sem uma síntese. Nessa mesma esteira é que podemos entender a crítica feita pelo filósofo ao positivo em Hegel.

Desse modo, Hegel e a herança moderna e iluminista são, em realidade, herdeiros do modelo filosófico grego e pagão, onde a ênfase reside na natureza. Assim, Pareyson aponta aqui, tal como já o fizeram Pascal e Kierkegaard, a diferença entre o paganismo e o cristianismo e o quanto compreender tal coisa parece importante para se perceber a linha de pensamento que se segue: "A diferença do pagão, que vê no sofrimento um evento natural e um fato, para um cristão é muito mais difícil suportar o sofrimento - mesmo que pareça exatamente o contrário - porque ele vê no sofrimento a pena do pecado e - portanto, a memória do pecado do qual ele é responsável, e não a natureza ou o destino" ${ }^{76}$

Talvez fique agora, então, mais claro como o cristianismo percebe o sentido do sofrimento e também o fato de o mal e o sofrimento se constituírem na base dessa reflexão ontológica do filósofo italiano. Assim, Pareyson explora um tema central da tradição cristã: o abandono de Cristo na cruz naquele momento de descrença e de profunda humanidade do próprio Deus. Em outras palavras, ocorre aqui uma dialética da cruz. Curiosamente, e pensando também em outras concepções religiosas, o filósofo compreende que o sofrimento possui uma ressignificação no cristianismo. Por isso, é preciso uma nova hermenêutica para tomá-lo não mais como masoquismo, inatividade ou mera passividade mas, ao contrário, perceber que "o sofrimento torna-se dessa maneira o portador do segredo do ser". ${ }^{77}$ Aqui reside um fulcro existencial da maior importância para ele e para boa parte do existencialismo cristão. A afirmação existencial da vitória sobre o mal. Em outras palavras: "Para vencer o mal é preciso, acima de tudo, que ele seja identificado e separado, observado e reconhecido, definido e devidamente condenado" ${ }^{78}$

Desse modo, inspirado em Orígenes e na sua tese da apocatástese, onde todas as coisas poderiam reencontrar a sua unidade em Deus e nele encontrar a redenção e a salvação, Pareyson vê aqui o único modo possível de conciliar totalidade e liberdade. Por isso, sua aposta é numa filosofia da escatologia:

$\mathrm{Na}$ escatologia nós podemos encontrar chaves decisivas para desenvolver e resolver os imbróglios, enredamentos de problemas humanos, lampejos iluminantes, aquilo que mais contêm sugestões, pressentimentos, rumores para o pensamento mais profundo. A escatologia é aquilo que contêm o

\footnotetext{
${ }^{76}$ PAREYSON, Ontologia da liberdade, 2017, p. 78.

77 PAREYSON, Ontologia da liberdade, 2017, p. 81.

${ }^{78}$ PAREYSON, Ontologia da liberdade, 2017, p. 81.
} 
segredo da filosofia e da teologia, e que mais tem a dizer sobre ambas; nesse sentido, é aquilo que conjuga os dois extremos da filosofia: a fantasia e o pensamento. ${ }^{79}$

Por isso, seguindo por essa senda das teses do cristianismo e em franco diálogo com os temas pascalianos, kierkegaardianos e da filosofia da escatologia, a conclusão de Pareyson é, em realidade, inconclusa, visto que de Deus pouco se pode falar ou definir. Assim, o filósofo é tentado a, no meio de tantas especulações, ensaiar uma tese ao modo mais sintético, ainda que não seja simplória: "A existência de Deus significa três coisas: o homem é pecador; o mundo tem um sentido; o mal acabará" (Pareyson, 2017, p. 87). Ao mesmo tempo, tal convicção é a base da afirmação do nosso ser, da nossa existência em sentido mais profundo.

\section{Considerações finais}

Em sua obra Studi sull'esistenzialismo, mas especificamente num capítulo intitulado Esistenzialismo 1939, o item 4 tem por título A existência como "insistência": situação e ontologicidade. Desta data, isto é, 1939, até 1988, momento em que foram ministradas as aulas de Pareyson sobre o problema da liberdade - que deram origem a obra Ontologia da liberdade - passaram-se quase 50 anos. Entretanto, de modo muito impressionante, notamos que os temas perseguidos pelo filósofo no decorrer da sua carreira acadêmica são os mesmos.

Não se trata aqui, evidentemente, de pensar que ele não tenha evoluído intelectualmente e nem que lhe faltasse "criatividade" para buscar outros temas. Aliás, trata-se exatamente do contrário disso. Contudo, o que merece destaque é que, em tal trajetória, o que se pode observar é cheio do mais rico significado: um pensador, formado na escola do existencialismo, como ele mesmo gostava de salientar, mostra-se como alguém que durante toda a vida parece ter percorrido um único objetivo: compreender filosoficamente o tema da liberdade e da existência nas suas diversas perspectivas.

Assim, o autor que inicia pelo existencialismo claramente tomado como tal, passa pela estética, passa pela hermenêutica, dialoga com a fenomenologia e com autores do porte de Kierkegaard, Pascal, Dostoievski, Schelling, Fichte e, a partir de tais fecundas aproximações, constrói a si mesmo e o seu modo de pensar.

Quando observamos com cuidado vemos que, na verdade, Pareyson "volta" ao seu tema de juventude. Mas aqui, talvez, caiba a reflexão: o que dizemos efetivamente ao afirmar que ele "volta"? Talvez a percepção mais adequada

${ }^{79}$ PAREYSON, Ontologia da liberdade, 2017, p. 83. 
seria perceber que há agora um novo olhar dentro do mesmo tema, sempre tão visto e tão estudado. Quiçá, como gostava de pensar Kierkegaard, haveria aqui uma repetição ou reapropriação cheia de significado ou, talvez como Feuerbach, igualmente por ele admirado, a perseguição, no melhor sentido dessa palavra, de um só tema que lhe foi tão caro durante toda a sua existência como condição para a construção de algo.

Tal coisa se constitui num exemplo, mas não para ser integralmente copiado pois, na medida em que a filosofia é também vida, experiência, ela serve para que, quando lemos um autor assim e com ele dialogamos efetivamente, descubramos mais quem somos nós próprios. Talvez o mote socrático do "conheça-te a ti mesmo" será sempre o ponto de partida (e de chegada) de toda a pesquisa filosófica.

\section{Bibliografia}

Arendt, H. Compreender - formação, exílio e totalitarismo, Companhia das Letras, São Paulo, 2008.

Cassirer, E. Filosofia do iluminismo, Unicamp, Campinas, 1997.

Kierkegaard, S.A. O Conceito de angústia, Vozes, Petrópolis, 2010. . Migalhas filosóficas, Vozes, Petrópolis, 1995.

Lourenço, E. Obras completas v. I - Heterodoxias [Ambiguidade do existencialismo; Situação do existencialismo], Calouste Gulbenkian, Lisboa, 2012.

Pareyson, L. Ontologia da liberdade - o mal e o sofrimento, Loyola, São Paulo, 2017. . Studi sull'esistenzialismo, Mursia, 2001.

Sartre, J.P. O existencialismo é um humanismo (Os Pensadores), Abril Cultural, São Paulo, 1987.

Stewart, J. Idealism and Existentialism - Hegel and the Nineteenth and - TwentiethCentury European Philosophy, Continuum, London, 2010.

Tillich, P. A Era protestante, Metodista, São Bernardo do Campo, 1992. . No limite, Fonte Editorial, São Paulo, 2016. Teologia da cultura, Fonte Editorial, São Paulo, 2009.

Endereço Autor:

Departamento de Filosofia

Universidade de Brasília

Campus Universitário Darcy Ribeiro

70910-900 Brasília - DF

marciogimenes@unb.br 